\title{
HUBUNGAN ANTARA USIA MENIKAH DENGAN KEJADIAN CA SERVIKS DI BKIA RSUUSD GAMBIRAN KOTA KEDIRI
}

\author{
Arika Indah Setyarini, Ira Titisari, Hetiningtiyas \\ Prodi Kebidanan Kediri, Jl. KH. Wakhid Hasyim No.64 B Kediri \\ Email : arika1mkeb@gmail.com
}

\begin{abstract}
The Correlation Between The Age of Married With Cervical Ca Events In Maternity Policlinic of RSUUSD Gambiran - Kediri City

Ca cervix is cancer that occurs on cervix, an area in which the female reproductive organ as the entrance towards the uterus located between the womb (uterus) with hole intercourse (vaginal). It was not just happen to women with marriage age $<16$ years, but also in women with marriage age $>16$ years. The purpose of this study was to investigate the relationship between age of marriage in the incidence of cervical $\mathrm{Ca}$. The research design used in this study is the analytic case control. This research was conducted at the medical record RSUUSD Gambiran of Kediri. The population in this study were all patients in the maternity policlinic of RSUUSD Gambiran - Kediri, which suffered from $\mathrm{Ca}$ cervix. The sampling was saturated sampling. The results, cervical $\mathrm{Ca} 42$ events during the period 1 January to 31 December 2012. The highest incidence in patients with marriage age $<16$ years $(69.05 \%)$. Data were analyzed using contingency coefficient test with $\mathrm{a}=$ 0.05 and $\mathrm{df}=1$, obtained no relationship between age of marriage in the incidence of cervical $\mathrm{Ca}$. Where women with marriage age $<16$ years of age have a higher risk of suffering from $\mathrm{Ca}$ cervix compared to women with marriage age $>16$ years. With the existence of the phenomenon it is necessary to increase the education and reproductive health education in adolescents with so expect teens can delay the age of marriage and sexual relations until the age of 20 years for healthy reproduction.
\end{abstract}

Keywords: Age of Marriage, Cervical Ca

\section{PENDAHULUAN}

Kanker serviks terjadi pada wanita yang telah berumur, tetapi bukti statistik menunjukkan bahwa kanker leher rahim dapat juga menyerang wanita yang berumur antara 20 sampai 30 tahun (Yohanes, Riono. 2007).

Penyebab langsung dari kanker servik belum di ketahui. Ada bukti kuat kejadiannya mempunyai hubungan erat dengan sejumlah faktor ekstrinsik, antara lain jarang ditemukan pada perawan (virgo), insidensi lebih tinggi pada mereka yang kawin daripada yang tidak kawin, insidensi meningkat dengan tingginya paritas, apalagi bila jarak persalinan terlampau dekat, mereka dalam golongan sosial ekonomi rendah (higiene seksual yang jelek, aktivitas seksual yang sering berganti-ganti pasangan / promiskuitas), jarang dijumpai pada masyarakat yang suaminya disunat (sirkumsisi), sering ditemukan pada wanita yang mengalami infeksi virus HPV (Human Popilloma Virus) - tipe 16 atau 18, pada wanita yang memilik kebiasaan merokok, dan pada gadis yang koitus pertama (coitarche) dialami pada usia amat muda ( $<16$ tahun) (Sarwono, P. 1999). Sedangkan dalam UU Perkawinan No. 1 Tahun 1974 Pasal 7 ayat (1) telah ditetapkan batas umur pernikahan yaitu 16 tahun untuk perempuan dan 19 tahun untuk laki-laki 
(www.indonesia.faihtfreedom.org/forum/v iewtopic. php).

Setiap tahun terdapat sekitar 20.000 penderita, $60 \%$ diantaranya diketahui setelah stadium lanjut dan $80 \%$ dapat disembuhkan. Biasanya saat terdeteksi, seputuh tahun sebelumnya sudah ada prakanker (http : // www . surya . co.id).

Angka kejadian Ca Serviks di dunia menyerang lebih dari 200.000 perempuan pertahun dan separuhnya terjadi di negara berkembang termasuk Indonesia yaitu 6.000 kasus di tiap propinsi dan merupakan penyebab kematian tertinggi kanker genetalia perempuan (http : // fk.unpad.ac.id / jsp / berita_detil.jsp? id_berita=0241020051). Di rumah sakit kanker Dharmais Jakarta pada tahun 1997 ditemukan 29 pasien kanker leher rahim (Erik Tapan. 2005).

Menurut data Medical Record RSUUSD Gambiran Kediri, angka morbiditas pasien rawat jalan dan rawat inap dengan kasus Ca Serviks menduduki peringkat pertama pada tahun 2004 terdapat 36 orang pasien atau 94,70\% dari seluruh kasus kanker ginekologi. Sedangkan pada tahun 2005 juga menduduki peringkat pertama yaitu terdapat 70 orang pasien atau 90,90\% dari seluruh kanker ginekologi. Adapun rincian kasus adalah sebagai berikut :

Tabel 1.1 Distribusi Kasus Ca Ginekologi RSUUSD Gambiran Kediri

\begin{tabular}{|c|c|c|c|c|c|c|c|c|c|}
\hline \multirow[b]{2}{*}{ No. } & \multirow[b]{2}{*}{ Tahun } & \multicolumn{6}{|c|}{ Kasus Ca Ginekologi } & \multirow[b]{2}{*}{$\begin{array}{l}\text { Juml } \\
\text { ah }\end{array}$} & \multirow[b]{2}{*}{$\%$} \\
\hline & & $\begin{array}{l}\text { Ser } \\
\text { vix }\end{array}$ & $\%$ & $\begin{array}{l}\text { Ovari } \\
\text { um }\end{array}$ & $\%$ & $\begin{array}{l}\text { Corpus } \\
\text { Uteri }\end{array}$ & $\%$ & & \\
\hline 1 & 2004 & 36 & 94,70 & 1 & 2,63 & 1 & 2,63 & 38 & 100 \\
\hline 2 & 2005 & 70 & 90,90 & 4 & 5,19 & 3 & 3,89 & 77 & 100 \\
\hline
\end{tabular}

Sumber : Medical Record RSUUSD Gambiran Kediri Tahun 2007

Berdasarkan tabel diatas didapat informasi bahwa kasus Ca Serviks pada tahun 2004 dan tahun 2005 dibandingkan dengan kasus $\mathrm{Ca}$ ginekologi yang lain menduduki peringkat pertama.

Berdasarkan data yang diperoleh selama praktek di BKIA RSUUSD Gambiran Kota Kediri tanggal 12-25 Pebruari 2012 didapatkan bahwa jumlah pasien yang mengalami kanker serviks yang memenuhi kriteria sebanyak 6 orang. Dari 6 orang tersebut 4 orang menikah usia $<16$ tahun dan 2 orang menikah pada usia 16 tahun.

Dengan adanya fenomena seperti yang tergambar dalam latar belakang, peneliti tertarik untuk melakukan penelitian tentang hubungan usia menikah dengan kejadian $\mathrm{Ca}$ Serviks periode 1 Januari - 31 Desember 2012 di BKIA RSUUSD Gambiran Kota Kediri.

\section{METODE PENELITIAN}

Populasi dalam penelitian ini adalah semua pasien $\mathrm{Ca}$ Serviks yang pernah memeriksakan diri di BKIA RSUUSD Gambiran Kota Kediri dalam periode 1 Januari - 31 Desember 2012 yaitu sebanyak 42 pasien. Sampel dalam penelitian ini adalah semua pasien $\mathrm{Ca}$ Serviks yang pernah memeriksakan diri di BKIA RSUUSD Gambiran Kota Kediri Periode 1 Januari - 31 Desember 2012. Dalam penelitian ini peneliti menggunakan sampling jenuh yaitu teknik penentuan sampel bila semua anggota populasi digunakan sebagai sampel (Sugiyono. 2002). Dalam penelitian ini variabel bebasnya adalah usia nikah. variabel tergantungnya adalah kejadian $\mathrm{Ca}$ Serviks. Alat ukur yang dipakai dalam penelitian ini adalah lembar checklist berdasarkan rekam medik. Analisa data menggunakan uji dengan uji korelasi koefisien kontingensi. Teknik ini mempunyai kaitan erat dengan Chi Kuadrat yang digunakan untuk menguji hipotesis komparatif sampel independen. Oleh karena itu rumus yang dipergunakan mengandung nilai chi Kuadrat. Rumus itu sebagai berikut :

$$
\mathrm{C}: \sqrt{\frac{X^{2}}{N+X^{2}}}
$$

(Sugiyono. 2002)

Harga Chi Kuadrat $\left(\mathrm{X}^{2}\right)$ rumusnya adalah :

$\mathrm{X}^{2}=\sum \frac{(f o-f h)^{2}}{f h}$

Keterangan : $X^{2}$ : Chi Kuadrat 
fo : Frekuensi yang diobservasi

fh: Frekuensi yang diharapkan

Untuk memudahkan perhitungan, maka data-data hasil penelitian perlu disusun kedalam tabel, kemudian masukkan hasilnya dalam rumus $\mathrm{X}^{2}$.

Hasilnya dibandingkan dengan nilai $\mathrm{X}^{2}$ tabel, dengan langkah sebagai berikut:

a. Lihat tabel $X^{2}$

b. Tentukan nilai $\alpha=0,05$

c. Tentukan derajat bebasnya $\rightarrow \mathrm{R}-$ $1=2-1=1$

Sehingga diperoleh nilai $\mathrm{X}^{2}$ tabel $=3,84$

Jika $X^{2}$ hitung $>X^{2}$ tabel maka Ha diterima ; ada hubungan.

Jika $\mathrm{X}^{2}$ hitung $<\mathrm{X}^{2}$ tabel maka Ho diterima ; tidak ada hubungan. (Sugiyono. 2002)

HASIL PENELITIAN

Kejadian Ca Serviks

\begin{tabular}{|c|c|c|}
\hline Usia Nikah & $\begin{array}{c}\text { Frekuensi } \\
\text { yang } \\
\text { diobservasi }\end{array}$ & $\begin{array}{c}\text { Frekuensi } \\
\text { Harapan }\end{array}$ \\
\hline$<16$ tahun & 29 & 21 \\
$\geq 16$ tahun & 13 & 21 \\
\hline Jumlah & 42 & 42 \\
\hline
\end{tabular}

Hasil penelitian yang dilaksanakan tanggal 18 - 19 Juni 2012 di BKIA RSUUSD Gambiran Kediri didapatkan 42 kejadian Ca Serviks selama periode 1 Januari s/d 31 Desember 2012. Dari 42 kejadian $\mathrm{Ca}$ Serviks, kesemuanya memenuhi criteria inklusi sebagai sampel penelitian.

\section{Usia Nikah Pasien yang Menderita Ca} Serviks

Dari tabulasi didapatkan data tentang usia nikah pasien yang menderita $\mathrm{Ca}$ Serviks sebagai berikut :

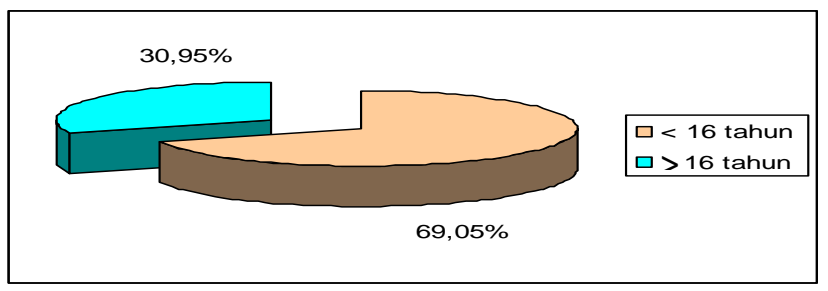

Diagram Pie Usia Nikah Pasien yang Menderita Ca Serviks
Dari gambar di atas didapatkan bahwa kejadian Ca Serviks pada usia nikah < 16 tahun yaitu sebanyak 29 orang $(69,05 \%)$ dan pada usia nikah $\geq 16$ tahun hanya 13 orang $(30,95 \%)$.

\section{Hubungan Usia Nikah dengan Kejadian Ca Serviks}

Untuk mengetahui hubungan antara variabel independen (usia nikah) dan variabel dependen (kejadian $\mathrm{Ca}$ Serviks) dilakukan uji koefisien

\begin{tabular}{|c|c|c|c|c|c|}
\hline Usia Nikah & fo & fh & $\begin{array}{c}\text { Fo } \\
- \\
\text { fh }\end{array}$ & $\begin{array}{c}(\text { fo } \\
\text { fh })^{2}\end{array}$ & $\begin{array}{c}(\text { fo }- \text { fh })^{2} / \\
\text { fh }\end{array}$ \\
\hline$<16$ tahun & 29 & 21 & 8 & 64 & 3,05 \\
$\geq 16$ tahun & 13 & 21 & -8 & 64 & 3,05 \\
\hline & & & & & 6,10 \\
\hline
\end{tabular}

kontingensi dengan terlebih dahulu dilakukan perhitungan chi kuadrat satu sampel. Adapun tabel hubungan usia nikah dengan kejadian Ca Serviks untuk perhitungan chi kuadrat sebagai berikut :

Tabel Chi Kuadrat Satu Sampel

Tabel Nilai Chi Kuadrat Satu Sampel Didapatkan nilai $\mathrm{X}^{2}$ hitung $=6,10$

Dengan menggunakan $\alpha=0,05$ dan derajat bebasnya $(\mathrm{df}) \rightarrow \mathrm{R}-1=2-1=1$, didapatkan nilai $\mathrm{X}^{2}$ tabel $=3,84$. Kemudian membandingkan nilai $X^{2}$ hitung dengan $X^{2}$ tabel didapatkan $X^{2}$ hitung $\geq X^{2}$ tabel maka hubungan antara usia nikah dengan kejadian Ca Serviks signifikan berarti Ha diterima yaitu ada hubungan antara usia nikah dengan kejadian Ca Serviks. Kemudian dilakukan penghitungan nilai $\mathrm{C}$ sebagai berikut :

$$
\begin{aligned}
C & =\sqrt{\frac{X^{2}}{N+X^{2}}} \\
& =\sqrt{\frac{6,10}{42+6,10}} \\
& =\sqrt{\frac{6,10}{48,10}} \\
& =\sqrt{0,127} \\
& =0,36
\end{aligned}
$$


Dan untuk mengukur hubungan, maka nilai $\mathrm{C}$ dibandingkan dengan nilai $\mathrm{C} \max$ dengan rumus sebagai berikut :

$$
\begin{aligned}
\mathrm{C} \max & =\sqrt{\frac{\mathrm{m}-1}{\mathrm{~m}}} \\
& =\sqrt{\frac{1-1}{1}} \\
& =\sqrt{\frac{0}{1}} \\
& =\sqrt{0} \\
& =0
\end{aligned}
$$

Dengan semakin dekat nilai $\mathrm{C}$ ke $\mathrm{C}$ max, dapat disimpulkan bahwa semakin besar derajat asosiasi antara usia nikah dengan kejadian Ca serviks.

\section{Pembahasan \\ Kejadian Ca Serviks}

Tabel tentang distribusi kasus $\mathrm{Ca}$ Ginekologi RSUUSD Gambiran Kota Kediri didapatkan hasil bahwa kejadian Ca Serviks tahun 2005 sebanyak 70 orang, sedangkan dari hasil penelitian yang telah dilaksanakan di BKIA RSUUSD Gambiran Kota Kediri pada tanggal 18-19 Juni 2012 didapatkan bahwa kejadian Ca Serviks selama tahun 2012 sebanyak 42 orang.

Hasil diatas dapat diketahui bahwa terjadi penurunan kejadian Ca Serviks dari tahun 2005 ke tahun 2012. Hal ini sesuai dengan pendapat para ahli kanker bahwa kanker leher rahim adalah salah satu jenis kanker yang paling dapat dicegah dan paling dapat disembuhkan dari semua kanker rahim (Yohanes, Riono. 2007).

Penurunan angka kejadian Ca Serviks di BKIA RSUUSD Gambiran Kota Kediri dari tahun 2005 ke tahun 2012 yang cukup signifikan yaitu 28 pasien (40\%) dikarenakan kesadaran pasien Ca Serviks untuk melakukan pengobatan secara rutin semakin meningkat. Dari data kontrol pasien Ca Serviks sendiri, meskipun mereka telah sembuh, mereka masih rutin melakukan pemeriksaan lanjutan berupa pemeriksaan "Pap Smear" setiap tahun sekali. Hal ini sesuai dengan pendapat para ahli kanker bahwa pemeriksaan lanjutan sesudah selesainya masa pengobatan adalah mutlak diperlukan untuk mendapatkan kepastian bahwa area yang telah diobati telah sembuh sama sekali. Biarpun metode pengobatan yang pasien dapatkan sangat efektif, sel-sel yang abnormal kadang-kadang dapat kambuh lagi, bahkan dapat berkembang dengan derajat keparahan yang lebih tinggi. Jadi deteksi dini adalah hal yang sangat esensial sekali. Selama dua tahun pertama masa pengobatan pasien, pasien disarankan untuk menjalani pemeriksaan "Pap Smear" setiap tiga bulan atau enam bulan sekali. Jika setelah tiga kali pemeriksaan berturut-turut hasil "Pap Smear" pasien normal, ini berarti pasien dapat dinyatakan sembuh, dan pasien dapat melakukan pemeriksaan "Pap Smear" setiap tahun sekali secara kontinyu (Yohanes, Riono. 2007).

\section{Usia Nikah Pasien yang Menderita Ca} Serviks

Gambar tentang usia nikah menunjukkan bahwa pasien yang menderita $\mathrm{Ca}$ Serviks didapatkan bahwa dari 42 pasien yang menderita Ca Serviks, terdapat 29 orang $(69,05 \%)$ dengan usia nikah $<16$ tahun dan 13 orang $(30,95 \%)$ dengan usia nikah $>16$ tahun.

Disini terlihat bahwa kejadian $\mathrm{Ca}$ Serviks lebih banyak terjadi pada pasien dengan usia nikah $<16$ tahun dibandingkan dengan usia nikah $\geq 16$ tahun, pasien dengan usia nikah $<16$ tahun memiliki risiko lebih tinggi dan merupakan salah satu faktor ekstrinsik penyebab terjadinya $\mathrm{Ca}$ Serviks. Hal ini dikarenakan seorang wanita menjalin hubungan seksual pada usia $<16$ tahun, dimana pada usia tersebut sel-sel mukosa pada serviks belum matang dan belum mencapai usia reproduksi sehat 20 tahun sehingga masih rentan terhadap segala bentuk rangsangan dari luar (www.surya.co.id).

Berdasarkan data yang diperoleh selama penelitian yang terlampir dalam 
lampiran 2, dari 29 orang dengan usia nikah < 16 tahun yang menderita $\mathrm{Ca}$ Serviks, didapatkan usia nikahnya berbeda yaitu : 2 orang dengan usia nikah 13 tahun, 10 orang dengan usia nikah 14 tahun dan 17 orang dengan usia nikah 15 tahun. Sedangkan pada 13 orang dengan usia nikah $\geq 16$ tahun, didapatkan usia nikahnya juga berbeda yaitu : 10 orang dengan usia nikah 16 tahun, 1 orang dengan usia nikah 17 tahun dan 2 orang dengan usia nikah 19 tahun.

\section{Hubungan Usia Nikah dengan Kejadian Ca Serviks}

Setelah dilakukan perhitungan menggunakan uji koefisien kontingensi dengan $\alpha=0,05$ dan $\mathrm{df}=1$, didapatkan adanya hubungan yang signifikan antara usia nikah dengan kejadian Ca Serviks. Selama periode 1 Januari s/d 31 Desember 2012 terdapat 42 kejadian Ca Serviks terbanyak terjadi pada usia nikah $<16$ tahun.

Kejadian Ca Serviks lebih banyak terjadi pada wanita dengan usia nikah < 16 tahun karena pada usia $<16$ tahun selsel mukosa serviks belum matang dan masih rentan terhadap rangsangan termasuk zat-zat kimia yang dibawa sperma. Karena masih rentan, sel-sel mukosa bisa berubah sifat menjadi kanker. Sifat sel sendiri bisa selalu berubah setiap saat, mati dan tumbuh lagi. Karena ada rangsangan, bisa saja sel yang tumbuh lebih banyak dari sel yang mati, sehingga perubahannya tidak seimbang lagi. Kelebihan sel ini akhirnya bisa berubah sifat menjadi sel kanker (Nasdaldy. 2007).

Berdasarkan data yang diperoleh selama penelitian di BKIA RSUUSD Gambiran Kota Kediri pada tanggal 18-19 Juni 2012 tentang Hubungan Usia Nikah Dengan Kejadian Ca Serviks Periode 1 Januari s/d 31 Desember 2012 didapatkan bahwa kejadian Ca Serviks juga dapat terjadi pada wanita dengan usia nikah > 16 tahun di karenakan faktor-faktor ekstrinsik yang lain diantaranya tingginya paritas : terdapat pasien primipara
$(2,38 \%), 26$ pasien multipara $(61,91 \%)$, dan 15 pasien grandemulti $(35,71 \%)$. Dari data diatas dapat diketahui bahwa $\mathrm{Ca}$ Serviks paling banyak diderita oleh pasien multipara.

\section{KESIMPULAN}

1. Terdapat 42 kejadian $\mathrm{Ca}$ Serviks selama periode 1 Januari s/d 31 Desember 2012 di BKIA RSUUSD Gambiran Kota Kediri. 35 orang merupakan pasien baru dan 7 orang merupakan pasien lama.

2. Kejadian Ca Serviks selama periode 1 Januari s/d 31 Desember 2012 yaitu sebanyak 29 orang dengan usia nikah < 16 tahun dan 13 orang dengan usia nikah > 16 tahun.

3. Dari hasil analisa data didapatkan adanya hubungan antara usia nikah dengan Ca Serviks periode 1 Januari s/d 31 Desember 2012 di BKIA RSUUSD Gambiran Kediri.

\section{SARAN}

Setelah melakukan penelitian tentang Hubungan Usia Nikah Dengan Kejadian $\mathrm{Ca}$ Serviks Periode 1 Januari s/d 31 Desember 2012 di BKIA RSUUSD Gambiran Kota Kediri dan memperoleh hasil penelitian tersebut, peneliti menyarankan kepada :

1. Lahan Penelitian

Dengan adanya peningkatan risiko terjadinya Ca Serviks pada usia nikah < 16 tahun maka perlu adanya peningkatan dalam pendidikan dan penyuluhan kesehatan reproduksi pada remaja sehingga diharapkan remaja dapat menunda usia nikah dan hubungan seksual sampai usia reproduksi sehat 20 tahun. Dalam hal ini diharapkan adanya kerjasama dari lahan penelitian dengan Dinas Kesehatan untuk pelaksanaan penyuluhan kesehatan reproduksi.

2. Peneliti selanjutnya

Diharapkan pada penelitian berikutnya di bahas faktor lain misalnya : kebiasaan merokok yang dapat meningkatkan resiko $\mathrm{Ca}$ Cerviks, atau 
pada faktor yang sama tetapi menggunakan cara pengumpulan data yang lain misalnya melalui interview atau wawancara langsung dengan pasien $\mathrm{Ca}$ Serviks sehingga data yang didapatkan lebih akurat.

\section{DAFTAR PUSTAKA}

Arikunto, S. 2002. Prosedur Penelitian (Rev. ed). Jakarta : Rineka Cipta

Danforth. 1996. Danforth's Handbook of Obstetrics \& Gynecology, TMA Chalik dan Huriawati, H. 2002 (Alih Bahasa), Jakarta : Widya Medika.

Erik Tapan. 2005. Kanker, Antioksidan, dan Terapi Komplementer. Jakarta : Gramedia.

Jong, Wim de. 2004. Kanker, Apakah Itu? Pengobatan, Harapan Hidup, dan Dukungan Keluarga. Jakarta : Arcan.

Naylor, C. Scott. 2000. Pocket Ob/gyn, Huriawati, H. 2004 (Alih Bahasa), Jakarta : EGC.

Nursalam. 2003. Konsep \& Penerapan Metodologi Penelitian Ilmu Keperawatan. Jakarta : Salemba Medika.

Price, Sylvia Anderson and Wilson, Borraine McCarty. 2002. Pathophysiology : Clinical Concepts Of Disease Processes, 6/e, Brahm U. 2005 (Alih Bahasa), Jakarta : EGC.

Rayburn, William F and Carey, J. Christopher. 1996. Obstetrics and Gynecology, TMA Chalik. 2001 (Alih Bahasa), Jakarta : Widya Medika.

Roem, S. 2001. Buku Acuan Teknik Pengambilan PapSmir. Surabaya. FK Unair.

Sarwono, P. 2002. Ilmu Kebidanan. Jakarta : YBP-SP.

Sarwono, P. 1999. Imu Kandungan. Jakrta : YBP-SP.

Soekidjo, N. 2002. Metodologi Penelitian Kesehatan (Rev ed). Jakarta : Rineka Cipta.
Sugiyono. 2002. Statistika untuk Penelitian $\left(4^{\text {th }} \mathrm{ed}\right)$. Bandung : Alfabeta.

Yohanes, Riono. 2007. Kc Leher Rahim, http//www.dokter.indo.net.id/ serviks/html, diakses tanggal 10 Maret 2007.

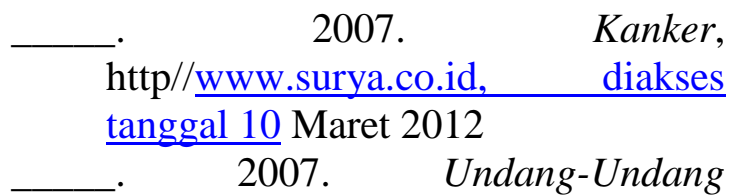
Perkawinan, http // www.pikiranrakyat.com / cetak / 1202 / 19/ 0305.htm, diakses tanggal 12 Maret 2012

2005. Undang-Undang Perkawinan, http// www.indonesia.faithfreedom. Org / forum / viewtopic.php, diakses tanggal 12 Maret 2012

Nasdaldy. 2007. Kanker Rahim, http : // lily37indo.multiplycom/journal, diakses tanggal 12 Maret 2012 . 2007. Wanita Sehat, http // www.geocities.com / wanitasehat / kr.html, diakses tanggal 12 Maret 2012 2007. Kanker Leher Rahim, http // www.fk.unpad.ac.id/jsp/berita_detil. jsp?id_berita $=0241020051$, diakses tanggal 24 Oktober 2012 